\title{
はんだ用熱疲労試験装置を用いた電子デバイスはんだの熱疲労寿命評価
}

\section{Thermal Mechanical Fatigue of Solders using Developed TMF Testing Machine for Solders}

\author{
○正 旭吉雅健（石川高専） 正 坂根政男（立命館大学） \\ 正 伊藤隆基（福井大学）
}

\begin{abstract}
Noritake HIYOSHI Ishikawa National College of Technology, Tsubata-machi, Kahoku-gun, Ishikawa, Japan. Masao SAKANE Ritsumeikan University, 1-1-1, Noji-higashi, Kusatsu-shi, Shiga, Japan.

Takamoto ITOH University of Fukui, 3-9-1, Bunkyo, Fukui-shi, Fukui, Japan.
\end{abstract}

Key Words: Thermal Mechanical Fatigue, Solder, Life Prediction, Testing Machine

\section{1. 緒 言}

はんだの熱疲労強度特性の把握は, 電子デバイスの信頼性 や製品の健全性保障のために重要である。近年，一定温度条 件下での低サイクル疲労などの研究報告は見られるように なったが，熱疲労に関する報告はほとんど少ない，また，等 温低サイクル疲労寿命と熱疲労寿命との関係について, 系統 的に検証した研究については, 著者らが知る限りでは見当た らない.

本研究では, はんだ用熱疲労試験装置を用いて $\mathrm{Sn}-37 \mathrm{~Pb}$ お よび Sn-3.5Ag の熱疲労試験を行い, 熱疲労寿命と等温呧サ イクル疲労寿命との関係について考察した。

\section{2. 実験方法}

熱疲労（TMF）試験は，電気油圧サーボ疲労試験機に温度 制御装置を取付けることによって行った。試験槽内の試験片 周辺の様子を Fig. 1 に示す. 加熱には $5 \mathrm{kw}$ の高周波誘導加熱 装置を用い, 出力を PID で調整して高温度側の温度を制御し た. 冷却にはコンプレッサーおよび 2 元冷凍式冷風発生装置 を用いて, 試験片に冷風を吹付けることによってサブゼロの 試験温度を可能とした。熱サイクル条件は $253 \mathrm{~K}\left(-20^{\circ} \mathrm{C}\right)$ 〜353K $\left(80^{\circ} \mathrm{C}\right)$ と設定した。昇降温速度は $1 \mathrm{~K} / \mathrm{s}$ である。

本研究で用いた試験片は外径 $10 \mathrm{~mm}$, 平行部長さ $15 \mathrm{~mm}$ を 有する中実丸棒試験片である。試験片標点部をエメリ一紙お よびバフで研磨し，その後組織安定化のために Sn-37Pb およ び Sn-3.5Ag それぞれの融点の 0.87 の温度で 1 時間の熱処理 を施した.

伸び計の固定には，試験片の表面に塗布した少量のエポキ シ樹脂にくぼみを設け，そのくぼみに伸び計先端を押し当て る方法 ${ }^{1)}$ を採用した。冷風吹付時には，伸び計に比較的強い 風が当たるが，伸び計からの信号には大きな乱れもなく，本 取付け方法は今回の TMF 試験に有効であることをあらかじ め確認している。 なお，伸び計で計測される全ひずみ $\left(\varepsilon_{\text {total }}\right)$ には機械的ひずみ $\left(\varepsilon_{\text {mech }}\right)$ と, 試験片の加熱・冷却に伴う熱ひ ずみ $\left(\varepsilon_{\text {thermal }}\right)$ とが含まれており, それらを分離して制御する 必要がある. 試験ソフトウェアのひずみ補正機能を用いてリ アルタイムに機械的ひずみを計算するために, 試験開始前に 荷重ゼロ制御のもとで数サイクルの加熱・冷却を行い，熱ひ ずみ曲線を計測した. 機械的ひずみが所定の值となるように ひずみを制御し, in-phase 型（高温・引張一低温・圧縮）お よび out-of-phase 型 (高温・圧縮一低温・引張) の実験を行 った. 熱疲労寿命 $\left(N_{f}\right)$ は引張側応力振幅が定常状態から 75\%に低下したサイクル数として定義した。

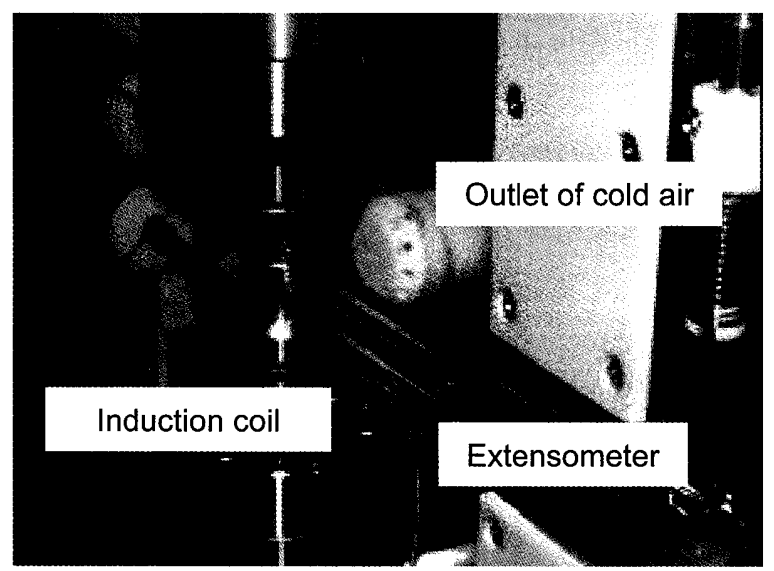

Fig. 1 Induction heating coil and cold air outlet.

\section{3. 実験結果および考察}

TMF 試験でのヒステリシスループ（応力一機械的ひずみ） の一例を Fig. 2 に示す. 同図(a)，(b)はそれぞれ in-phase 型, out-of-phase 型の結果であり，図中の実線は $\mathrm{Sn}-37 \mathrm{~Pb}$ ，破線は Sn-3.5Ag を示している. TMF 試験のすべてのヒステリシス ループ形状が，等温低サイクル疲労 (LCF) 試験でのそれと 大きく異なる特徴をもっている. すなわち, LCF 試験でのル 一プ形状には，一般に応力とひずみがゼロとなる点を中心と した点対称性が見られるが，TMF 試験でのそれには点対称 性がない.一方, in-phase 型のループ形状と out-of-phase 型の それとを比べると，互いに $180^{\circ}$ 回転した関係にある。

図(a)に示した in-phase 型の応力振幅は, Sn-37Pb の高温・ 引張側で+31MPa，低温・圧縮側では一 $45 \mathrm{MPa}$ であり，絶対 值は約 1.5 倍の差を生じていた. Sn-3.5Ag では，高温・引張 側で+25MPa，低温・圧縮側でー36MPa であり，Sn-37Pb と 同様に低温・圧縮側の応力振幅が高温・引張側のそれよりも 1.4 倍となった。

図(b)の out-of-phase 型でも低温・引張側と高温・圧縮側と で顕著な応力振幅差が見られた。すなわち, Sn-37Pb の低温 ・ 引張側の応力振幅は+42MPa であり, 高温・圧縮側でのー 27 $\mathrm{MPa}$ に比べると約 1.6 倍であった. Sn-3.5Ag の低温・引張側 では+38MPa であり，高温・圧縮側でのー26MPa よりも 1.5 倍であった。

Sn-37Pb および Sn-3.5Ag の in-phase 型, out-of-phase 型のす ベての結果で, 熱サイクルが低温度となる側の忘力振幅が大 きい。これは，低温度環境では，はんだの変形抵抗が大きく なることに拠ると思われる，また，詳細は後述するが，両は 


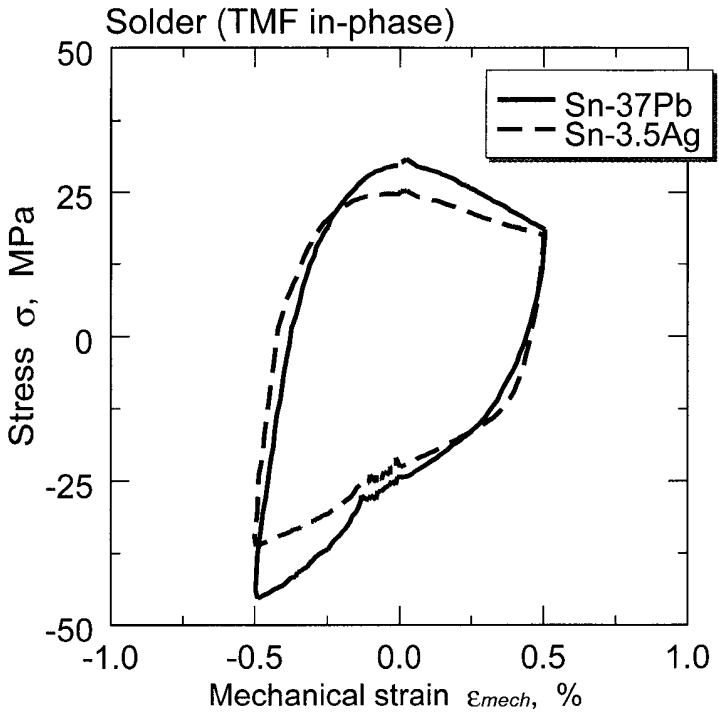

(a) In-phase (high temp.-tension / low temp.-compression) test

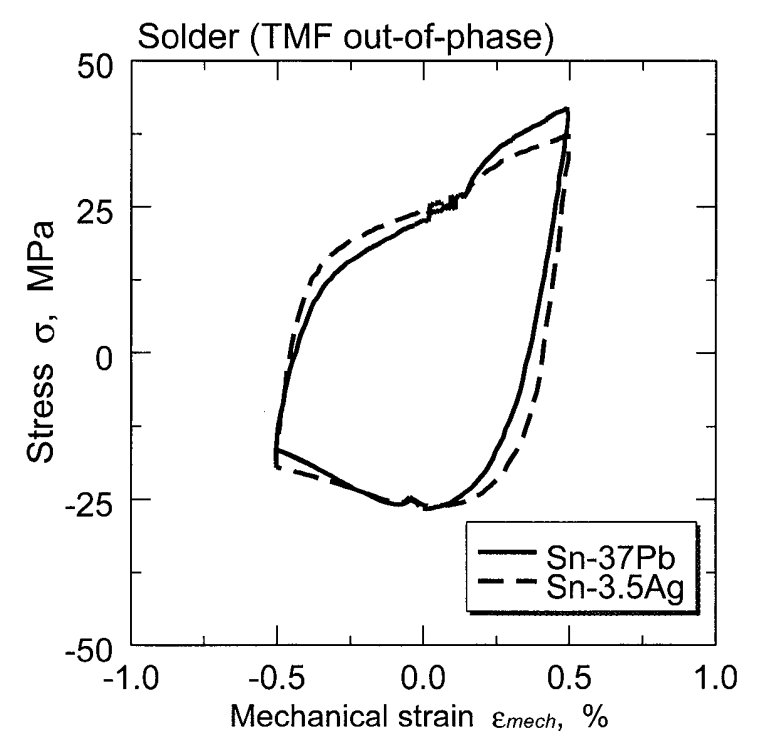

(b) Out-of-phase (low temp.-tension / high temp.-compression) test Fig. 2 Hysteresis loop of TMF test.

\section{Sn-37Pb Solder}

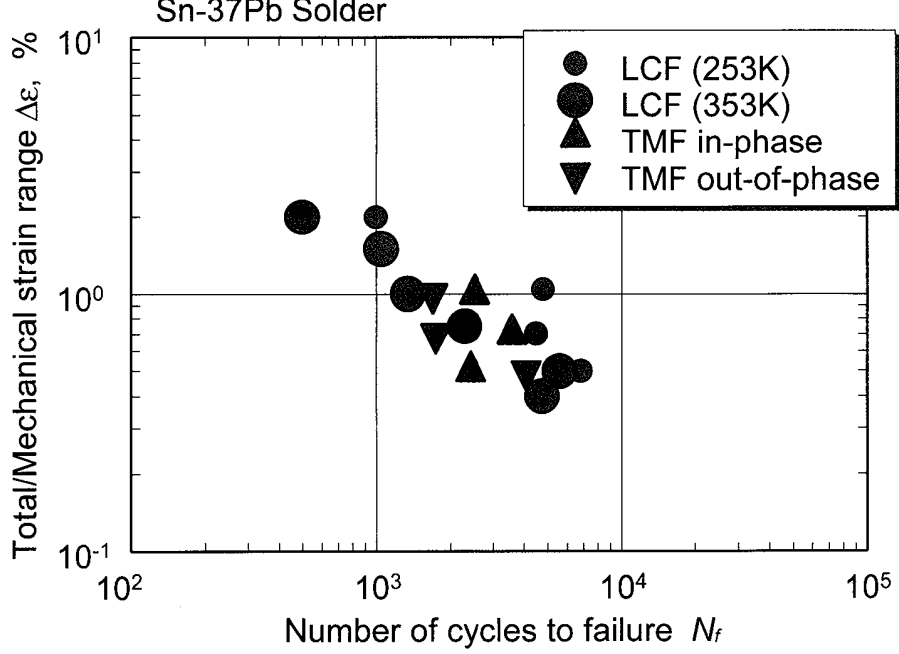

(a) $\mathrm{Sn}-37 \mathrm{~Pb}$

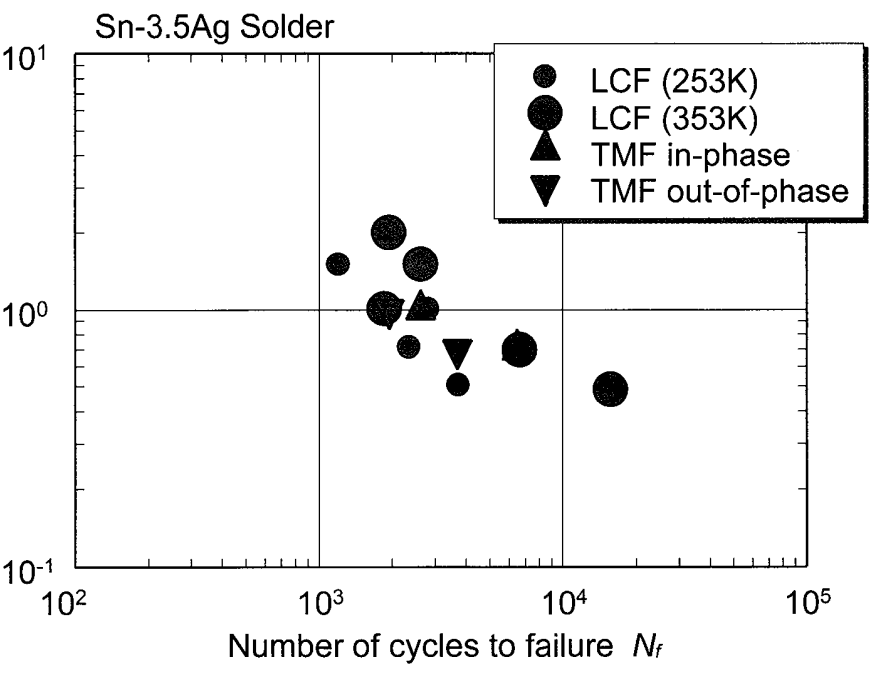

(b) Sn-3.5Ag

Fig. 3 Correlation of fatigue lives with total/mechanical strain ranges.

んだの TMF 試験の寿命は，同一ひずみ範囲において in-phase 型よりも out-of-phase 型が短寿命となる傾向があった. Fig. 2 に示すように TMF 実験中は，in-phase 型では圧縮側の平均応 力が生じ, 逆に out-of-phase 型では引張側の平均応力が生じて いる. この out-of-phase 型で生じる引張側の平均态力が, 比較 的短寿命となった要因として考えられる.

TMF 試験と LCF 試験の寿命整理結果を Fig. 3 に示す. 両者 のデータ比較を簡便に行う目的で, TMF 試験については機械 的ひずみ範囲 $\left(\Delta \varepsilon_{\text {mech }}\right)$ を, LCF 試験は全ひずみ範囲 $\left(\Delta \varepsilon_{\text {total }}\right)$ を

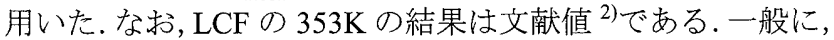
耐熱鋼の TMF では，in-phase 型は out-of-phase 型よりも短寿 命となることが知られているが，Sn-37Pb および Sn-3.5Ag で は，以下のように耐熱鋼の TMF 寿命と異なる傾向であった。

Fig. 3 (a)は Sn-37Pb の結果で, in-phase 型の方が out-of-phase 型よりもやや長寿命となる傾向が見られるが, それらの寿命 差は比較的小さく, Sn-37Pb の TMF 寿命におよぼす位相差の 影響は少ないと言える. TMF と LCF とを比較しても， LCF の $253 \mathrm{~K}, \Delta \varepsilon_{\text {total }}=1.0 \%$ の結果がやや長寿命となっているもの の，す心゙ての実験結果でデータのばらつきは小さく，寿命に 及ぼす TMF と LCF の違いの影響は小さい.

同図(b)は Sn-3.5Ag の寿命整理結果であるが，Sn-37Pb と同
様に in-phase 型が out-of-phase型よりも長寿命であった.また， TMF と LCF とを比較すると, TMF の in-phase 型寿命は, 熱 サイクルの上限温度での LCF 寿命と同程度であった。一方, TMF の out-of-phase 型寿命は熱サイクルの下限温度での LCF 寿命とほぼ等しい結果であった。ここで, Fig. 3 (b)に示すよ うに Sn-3.5Ag の $253 \mathrm{~K}$ および $353 \mathrm{~K}$ の LCF 寿命は, 係数 2 の ばらつき範囲内に整理されている. 今回実験を行った条件で の TMF 寿命データも, in-phase 型と out-of-phase 型とで寿命 差があるものの, LCF 寿命のばらつきと同様に係数 2 の範囲 内に整理される結果であった。

上述のように, Sn-37Pb の TMF 寿命と LCF 寿命は概して一 本の直線上にプロットできる結果であった. Sn-3.5Ag の TMF 寿命は, 該当する試験温度での LCF 寿命と同程度であった. したがって, Sn-37Pb および Sn-3.5Ag の TMF 寿命評価につい て, 等温 LCF データを用いて簡便に評価することの有効性が 示唆された.

\section{参考文献}

1) はんだの低サイクル疲労試験法標準, 日本材料学会 (2000).

2) Factual Database on Tensile and Low Cycle Fatigue Properties of $\mathrm{Sn}-37 \mathrm{~Pb}$ and $\mathrm{Sn}-3.5 \mathrm{Ag}$ Solders, The Society of Materials Science, Japan (2001). 